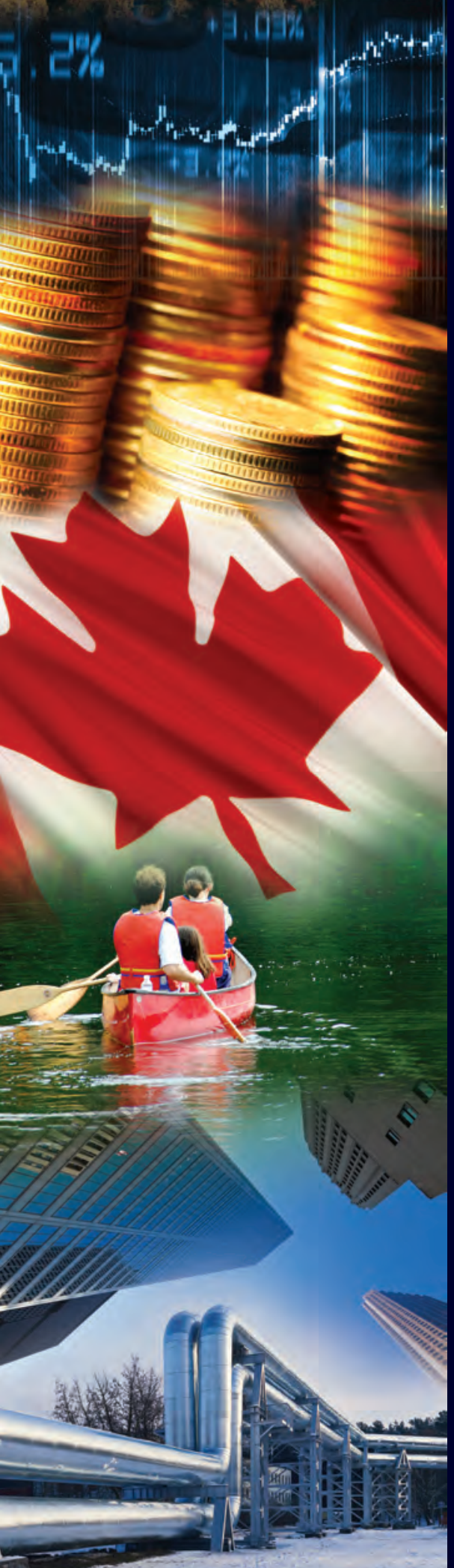

institut C.D. HOWE institute

COMMENTARY

NO. 478

\section{Defining the \\ Public Interest in \\ Regulatory Decisions: The Case for \\ Economic Efficiency}

Canada's public utility regulators are under mounting public and judicial attack. Many of the concerns regarding regulatory decisions would vanish, or be minimized, if governments clearly articulated in law that regulators should base their decisions solely on economic efficiency grounds.

Jeffrey Church 


\section{THE C.D. HOWE INSTITUTE'S COMMITMENT TO QUALITY, INDEPENDENCE AND NONPARTISANSHIP}

\section{ABOUT THE AUTHOR}

Jeffrey Church is Professor of Economics, Department of Economics, University of Calgary.

Commentary No. 478

May 2017

Public Governance and

Accountability
The C.D. Howe Institute's reputation for quality, integrity and nonpartisanship is its chief asset.

Its books, Commentaries and E-Briefs undergo a rigorous two-stage review by internal staff, and by outside academics and independent experts. The Institute publishes only studies that meet its standards for analytical soundness, factual accuracy and policy relevance. It subjects its review and publication process to an annual audit by external experts.

As a registered Canadian charity, the C.D. Howe Institute accepts donations to further its mission from individuals, private and public organizations, and charitable foundations. It accepts no donation that stipulates a predetermined result or otherwise inhibits the independence of its staff and authors. The Institute requires that its authors publicly disclose any actual or potential conflicts of interest of which they are aware. Institute staff members are subject to a strict conflict of interest policy.

C.D. Howe Institute staff and authors provide policy research and commentary on a non-exclusive basis. No Institute publication or statement will endorse any political party, elected official or candidate for elected office. The Institute does not take corporate positions on policy matters.
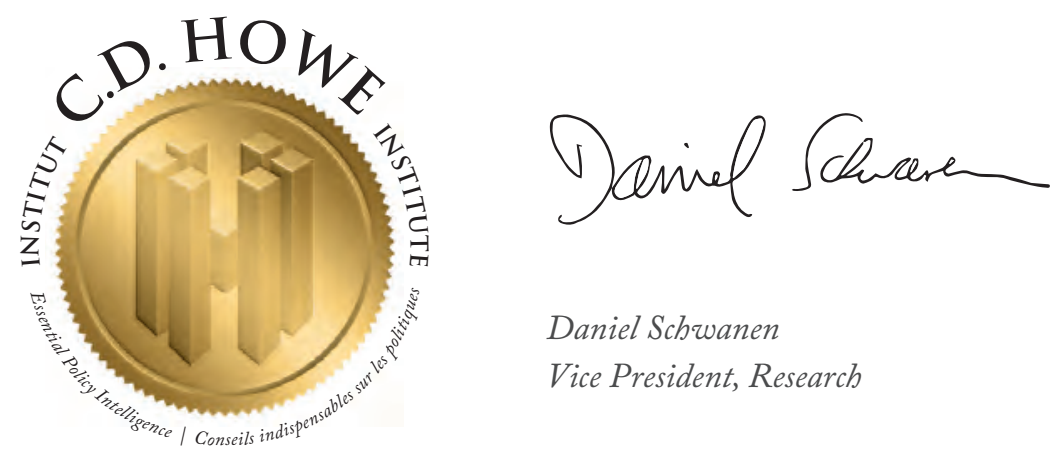

Daniel Schwanen

Vice President, Research 


\section{THE STUDY IN BRIEF}

Canada's public utility regulators - in sectors ranging from energy to telecommunications - are under attack. Regulators and their decisions have been subject to withering commentary, hostility, disbelief, contempt and even disobedience.

Many of the concerns regarding regulation arise because their enabling legislation does not clearly articulate the purpose of regulation. The goal of regulation should be to maximize the value of production from Canada's scarce resources, its land, natural resources, capital, and labour. The only goal of regulation should be economic efficiency: maximizing the wealth of the nation. But, it usually is not.

In circumstances when markets do not deliver efficiency, for instance when firms degrade the environment without paying or have monopoly power, intervention by an independent regulator can promote investment, economic growth, and rising standards of living. For intervention to be more likely to have these positive effects, the sole mandate of the regulator needs to be promoting efficiency.

Instead, many governments provide regulators with a vague mandate to act in the public interest, or multiple, often conflicting objectives. That leaves regulators with far too much latitude to be influenced by lobbying, rent seeking, and political influence. Indeed, to minimize the potential for exchanges between politicians and special interest groups involving favourable policy in return for cash and votes, it is important that governments delegate regulatory decisions to independent regulators (handcuffed by an efficiency mandate), and not leave regulatory decisions to politicians.

Issues such as income distribution are too important for governments to delegate to autonomous unelected regulators. The issue of the appropriate distribution of income, which fundamentally involves taking from one group of citizens and giving to another, should be determined in the political process. Regulatory processes are not a substitute forum for the expression of preferences over the distribution of income and resource development. Some of today's social frustration with regulation is a result of it being asked to decide whose preferences are more worthy, a task for which regulators are ill-suited. Instead, regulators with an efficiency mandate would focus only on aggregate costs and benefits. Such a renewed focus would have important, beneficial, implications for the practice of regulation.

An advantage to society of an economic efficiency mandate is that a regulator can more readily resist demands that, in the short run, have immediate benefits for some, but in the long run destroy the incentive for investment and wealth creation. It is time that governments across Canada refocus regulators with an explicit and singular mandate to improve economic efficiency.

C.D. Howe Institute Commentary $($ is a periodic analysis of, and commentary on, current public policy issues. Michael Benedict and James Fleming edited the manuscript; Yang Zhao prepared it for publication. As with all Institute publications, the views expressed here are those of the author and do not necessarily reflect the opinions of the Institute's members or Board of Directors. Quotation with appropriate credit is permissible.

To order this publication please contact: the C.D. Howe Institute, 67 Yonge St., Suite 300, Toronto, Ontario M5E 1J8. The full text of this publication is also available on the Institute's website at www.cdhowe.org. 


\section{Canada's public utility regulators - those responsible for prices and entry permits in electricity transmission, telecommunications and petroleum pipelines, among others - are under mounting public and judicial attack.}

The perception, reflected in the large number of court challenges and public protests, is that public utility regulation is, in many cases, broken. Regulator decisions and the conduct of regulatory hearings have been subject to withering commentary, hostility, disbelief, contempt and even disobedience. ${ }^{1}$ Examples of negative commentary on regulatory decisions are not hard to find, crossing jurisdictions and sectors, including: pipeline approvals by the National Energy Board (NEB) (Doucet 2012; Colton et al. 2016); wireless contracts, bundling of television channels, and mandated access to incumbent telephone networks at the Canadian Radio-television and
Telecommunications Commission (CRTC) (Dachis and Schwanen 2016); and pricing and facilities approval of electricity transmission by the provincial regulator in Alberta (Church et al. 2009).

The perception that economic regulation is broken has invited an unproductive political response that realigns authority and responsibility away from traditional independent regulatory boards and tribunals to governments. Examples of this government involvement include the pricing and availability of electricity transmission in Alberta, ${ }^{2}$ the roaming rates paid by smaller wireless companies when their customers utilize another provider's network, ${ }^{3}$ the approval of interprovincial

This Commentary is based on a presentation made to the C.D. Howe Institute's Energy Policy Council. I am grateful for their feedback and encouragement. Extensive comments from Ben Dachis, other internal reviewers at the C.D. Howe Institute and three external referees substantially improved the presentation and content. Their contributions are gratefully acknowledged.

1 Some examples of disobedience and contempt with respect to regulatory process and decisions are shown in Box 1. In addition, Colton et al. (2016, p.1) document other public protests over regulatory decisions and court challenges to NEB decisions.

2 The Government of Alberta overruled the Alberta Energy and Utilities Board's locational-pricing decision for electricity transmission, replacing it with a scheme that recovers most of the transmission costs directly from consumers, and it moved approval authority for critical transmission infrastructure from the Alberta Utilities Commission to cabinet. See Church et al. (2009) for details.

3 The Government of Canada's 2014 budget limited the amount a wireless carrier can charge for domestic roaming services provided to rivals (Canada 2014). 
pipelines, ${ }^{4}$ and even the volume of grain railroads are required to move in a week. ${ }^{5}$

I attribute the turmoil around regulation - both its institutions, processes and decisions - to a fundamental misunderstanding of the rationale for regulation and, hence, a failure to define, or correctly identify, the objectives of regulation. Many of the concerns regarding regulatory decisions and the regulatory process would vanish, or be minimized, if governments clearly articulated in law that regulators should base their decisions solely on economic efficiency grounds. With this change in law, regulators would instead focus their efforts on economic efficiency rather than on the usual appeal to the public interest, which is typically undefined, and other vague objectives found in existing legislation, such as "just and reasonable tolls." Economic efficiency simply means the maximization of the value of production, or in Adam Smith's terms, maximization of the wealth of the nation.
It is poor institutional design for legislatures to allocate responsibility for other important issues that may arise in regulatory decisions to the regulators, in particular a decision's incomedistribution implications. Regulators are also not the appropriate bodies to consider environmental goals and the definition and scope of Aboriginal rights outside of the efficient allocation of resources. ${ }^{7}$ Instead, there should be an institutional division of labour. Legislative branches should be responsible for determining public policy matters, such as appropriate income distribution, and implementing policy measures to that effect. The objective appropriate for an autonomous, unelected regulatory body is economic efficiency. Moreover, when efficiency is the objective, regulatory authority should not reside with governments, since distributional considerations will likely then dominate the decision-making process.

4 The previous government expanded cabinet oversight of the NEB in 2012. Prior to amendments introduced in the 2012 federal budget, interprovincial pipelines were required to obtain a certificate of public convenience and necessity as a condition of operation. The NEB issued such certificates subject to the approval of cabinet. However, in 2012 cabinet oversight expanded to include both NEB approval and denial of certificates (Canada 2012). The current federal government has promised a new environmental assessment process it argues is necessary to restore public trust and has also promised to modernize the NEB (Canada 2016a). Meanwhile, as an interim measure, the federal government imposed additional conditions on two proposed oil pipelines. For the Trans Mountain Expansion Project - which had already been approved by the NEB - Ottawa delayed cabinet approval until after it undertook "deeper consultations with Indigenous peoples" and appointed a "Ministerial Representative" to "engage communities" and "seek their views and report back to the Minister of Natural Resources" (Canada 2016a). The federal government approved the Trans Mountain Expansion Project after additional consultations and Ministerial review (Canada 2016b and 2016c). For the Energy East Pipeline, the federal government will not only undertake and fund "deeper consultations with Indigenous peoples," but it will "facilitate expanded public input into the National Energy Board review process” (Canada 2016a).

5 See Dachis (2015) for discussion and analysis of the federal government's minimum quantity grain shipping order.

6 Under the National Energy Board Act, the NEB is instructed to use its powers to further the public interest. Under Section 12(1)(b) "where it appears to the Board that the circumstances may require the Board, in the public interest, to make any order or give any direction, leave, sanction or approval that by law it is authorized to make or give, or with respect to any matter, act or thing that by this Act or any such regulation, certificate, licence, permit, order or direction is prohibited, sanctioned or required to be done." Also, when considering approval of a permit application, the NEB is to "consider any public interest that in the Board's opinion may be affected by the issuance of the certificate or the dismissal of the application." But when it comes to tolling, the NEB is instructed to insure that they are "just and reasonable" and do not "unduly discriminate" (Sections 62 and 67). As with the public interest, "just and reasonable" and "undue discrimination" are not defined.

7 As noted later in this Commentary these are legitimate public policy concerns but to the extent they do not involve the efficient allocation of resources, they are related to the appropriate distribution of income. 


\section{PUBLIC INTEREST AND REGULATION}

\section{Box 1: Regulatory Roadblocks in Canadian Energy}

\begin{tabular}{|c|c|}
\hline $\begin{array}{l}\text { Electricity in } \\
\text { Alberta }\end{array}$ & $\begin{array}{l}\text { Chaos and alleged physical abuse of Alberta Energy and Utilities Board (AEUB) staff at a hearing to determine the } \\
\text { routing of high voltage transmission lines. Security concerns led the AEUB to hire private investigators who infiltrated } \\
\text { landowners opposed to the lines and who had been effectively excluded from the first stage of the two-stage process, } \\
\text { determining the need for the lines. The three members of the AEUB panel subsequently resigned and the AEUB was } \\
\text { divided into the Energy Resource Conservation Board and the Alberta Utilities Commission (CBC News 2007). For a } \\
\text { detailed account of this hearing and an analysis of the regulatory procedure, see Woolley (2008). }\end{array}$ \\
\hline Energy East & $\begin{array}{l}\text { The NEB was forced to suspend its hearing over the proposed Energy East pipeline due to security concerns after violent } \\
\text { protestors disrupted the first day of hearings (see Cattaneo 2016a and National Energy Board 2016a). Opponents of the } \\
\text { Energy East pipeline, based on concerns over panel bias, were successful in having the initial panel replaced (because two } \\
\text { members of the NEB panel had meet, unbeknown to them, with a lobbyist employed by the proponent, TransCanada } \\
\text { Pipelines) and the hearings delayed. The Chair and Vice-Chair recused themselves from exercising their administrative } \\
\text { duties of appointing a replacement panel because of their participation in engagement meetings that included the } \\
\text { TransCanada lobbyist (Cattaneo 2016b; National Energy Board 2016b; National Energy Board 2016c). The federal } \\
\text { government has appointed three new members to the NEB and they were assigned by the Acting Chair of the National } \\
\text { Energy Board to review the Energy East proposal. (National Energy Board 2016d and 2017a). The new panel has voided } \\
\text { all of the decisions of the previous panel and the hearing process will start anew (National Energy Board 2017b). }\end{array}$ \\
\hline $\begin{array}{l}\text { Northern } \\
\text { Gateway }\end{array}$ & $\begin{array}{l}\text { The Federal Court of Appeal overturned the regulatory approval for Northern Gateway. The previous federal government } \\
\text { had issued a permit based on the findings and recommendations of the NEB (McCarthy and Lewis 2016). However, } \\
\text { the BC government made it clear that unless five conditions were met, it would actively oppose and seek to block } \\
\text { construction of Northern Gateway, as well as expansion of the Trans Mountain pipeline (British Columbia 2012). Indeed, } \\
\text { the BC Environment Minister responded to the NEB's conditional Northern Gateway approval with threats to withhold } \\
\text { provincial permits if the five conditions were not met (Hunter and Stueck 2014). The federal government determined that } \\
\text { the Northern Gateway Pipeline was not in the public interest and overturned the NEB's approval (Canada 2016b). }\end{array}$ \\
\hline Trans Mountain & $\begin{array}{l}\text { The NEB limited access to its hearing rooms during oral summary arguments in the Trans Mountain expansion } \\
\text { proceeding based on "the past history of disruptions and the publicly available information regarding occurrences of } \\
\text { civil disobedience associated with the Project" (National Energy Board 2015). Public protest over the Trans Mountain } \\
\text { Expansion resulted in numerous arrests and comment by observers that the NEB process was "fundamentally flawed" } \\
\text { and a "sham" (McSheffrey and Uechi 2016). Ottawa's endorsement of the NEB's Trans Mountain approval resulted in } \\
\text { demonstrations in Vancouver and the filing of a request for judicial review, bringing the total number of legal challenges } \\
\text { contesting the approval to at least eight (Cheadle 2017). } \\
\text { The Government of British Columbia has confirmed that its five conditions have been met (Government of British } \\
\text { Columbia } 2017 \text { ) and it issued an environmental assessment certificate. To satisfy the five conditions, the proponent of } \\
\text { the Trans Mountain Expansion agreed to another } 37 \text { environmental conditions above and beyond the } 157 \text { of the NEB, } \\
\text { to spend } \$ 150 \text { million on enhanced oil spill response measures, and to payments of up to } \$ 1 \text { billion to the B.C. } \\
\text { government. Environmental groups have sued for a judicial review of the environmental assessment certificate. Their } \\
\text { grounds for it being overturned are } \$ 560,000 \text { in donations to the governing party from the project's proponent and } \\
\text { others with an alleged commercial interest in the pipeline sector (Bailey 2017). }\end{array}$ \\
\hline
\end{tabular}


There are three fundamental issues related to the definition and role of the "public interest" in the context of public utility regulation. Understanding these issues explains why economic efficiency should be the sole objective of regulation, as well as insight and guidance into the importance of designing regulatory institutions that implement economic efficiency.

The first issue is, why regulate in the first place? That is, what is the rationale that justifies restricting the choices made by willing buyers and sellers in markets? It is worth emphasizing that the accumulated wisdom of successful economies is that markets, in most cases, are effective in allocating resources, providing consumers with many choices at reasonable prices; i.e., prices that track costs. ${ }^{8}$

The second issue is, if regulatory intervention is justified, why allocate regulatory decisions to regulators? Why would governments ever delegate the authority and responsibility for making such decisions to independent, non-elected, third parties? Governments could make these decisions and be responsible for their outcome, rather than assign them to a regulator, especially when these decisions potentially have an enormous impact on the lives of Canadians, as in the case of the price, reliability and availability of electricity. ${ }^{9}$

Finally, the third issue is, how should governments provide instruction to independent regulators when they apply their decision-making authority. Should governments define the public interest in enabling legislation or simply specify that regulation is to be in the public interest? In defining the public interest, should the legislation contain specific goals that inform how the regulator is to determine the public interest, like requiring prices to be just and reasonable or non-discriminatory? Alternatively, the enabling legislation could contain detailed rule making that is prescriptive. For instance, the enabling legislation could instruct the regulator on how it is to set prices so that they are equal to cost of service, where the determination of the cost of providing service is specified in more or less detail in the legislation.

The answer to these three questions should be based on an analysis of how governments actually make choices, as opposed to how we would like them to make choices.

\section{Public Choice And Regulation}

The field of Public Choice is the study of how governments make decisions. Its application to regulation begins with two simple, but powerful, premises. ${ }^{10}$ First, politicians and political parties are self-interested economic actors. Second, government has a monopoly on the legal power of coercion. Only the government can legally use force to achieve an outcome it deems desirable.

The implication of these two premises is that there will be a market for this legal coercive power. Private interests will seek it, while governments and political parties, in exchange for votes and resources, will offer it. ${ }^{11}$ This suggests that there should be narrow bounds on government authority in general and on regulatory discretion in particular. It is naïve

8 See Watson (2015, xii-xiii), Acemoglu and Robinson (2012, Chapter 3) or Ferguson (2011).

9 In Ontario, the provincial government oversees electricity provision. The results have been sufficiently perverse that its regulatory oversight is a campaign issue and the topic of editorials in the Globe and Mail. See for example Globe and Mail (2016) and Wente (2016).

10 For a discussion of the foundations of Public Choice and its history, see Mueller (2003, Chapter 1). The discussion in this Commentary is based on the development and application of Public Choice to regulation. Seminal works are Stigler (1971), Posner (1972) and Petlzman (1976). For an introduction to the topic, see Noll (1989) or Church and Ware (2000, Chapter 24).

11 Recent news reports have highlighted provincial and federal politicians selling access to private donors in Ontario and BC. See, for example, Coyne (2016), Morrow (2016) and the National Post (2016). 
to ignore the potential for government discretion to be used to promote private interests.

The successful bidders in the market for coercion purchase the ability to influence policy and its implementation in their favour, either through an increase in their incomes or by promoting an allocation of resources consistent with their preferences. ${ }^{12}$ Viewed from this perspective, much of government policy and regulatory discretion is seen as a redistributive exercise - redistributing income either directly or indirectly.

When an environmental lobby group is able to influence policy to restrict development of a resource, the redistribution is indirect. The effect of the policy restriction is the same as if the government had transferred income to the lobby group members, they used their higher income to buy the resource and then, as its owners, restricted its development. In this way, income and government policy are substitutes - either can be used to control the use of resources.

The danger, given the importance of institutional design for economic development and relative national prosperity, is that distribution choices will dominate policy discussions (Acemoglu and Robinson 2012). Indeed, this has been a very important consideration in explaining the poor performance of regulated industries (Spiller and Tommasi 2005). With inappropriate institutions, groups that are powerful politically end up with a veto over policy, and economic efficiency is crowded out by distributional concerns, with long-run implications that are decidedly negative for a society's standard of living and economic development. The solution to this problem is not only to try and make the exchange - cash and votes for favourable policy - between governments and special interest groups more difficult. The answer should also encompass efforts to reduce, or limit, the ability of governments to use their discretion to affect the allocation of resources.

\section{EFFICIENCY AND REGULATION}

\section{What is Economic Efficiency?}

An outcome is economically efficient if the value of production from society's endowment of resources - its capital, labour and natural resources - is maximized. For example, in determining whether land should be used for a park, housing, agriculture or transport of petroleum products, the efficient outcome is to use the land to produce what society values the most. If drivers of automobiles value transportation sufficiently, then demand for gasoline will be sufficiently high that oil companies can outbid lovers of green space and the land will, and should, be used for a pipeline. Intuitively, economic efficiency is about using resources in their first-best use, and the costs of misallocating resources is the difference in value between using those resources in their second-best instead of first-best use. ${ }^{13}$

As Adam Smith observed, a voluntary trading process that is competitive results in an efficient state: at the end of the trading process, all trades that are mutually beneficial will be made as a result of the "invisible hand." The consequence is that the value of resources is maximized: no one is willing

12 In a world of imperfect information and transaction costs, the competition among special interest groups will favour those groups that can more quickly and effectively reach consensus as well as extract more resources from its members and limit free riding (i.e., when individuals with similar interests are made better off by the lobbying and monitoring efforts of a special interest group but do not support it financially). Because of these differences, lobbying by special interest groups will not result in efficiency (Church and Ware 2000, pp. 773-774).

13 Any society's standard of living depends upon the extent to which it can maximize the production value from its endowment: land, natural resources, capital and labour. Inefficient outcomes result in lower levels of productivity and a lower standard of living. 
to outbid anyone else to reallocate resources. ${ }^{14}$ Any reallocation may benefit one person, but only at the cost of harming another. In practice, however, market economies are dynamic, and the competitive outcome changes with shocks to supply and demand. Those changes create both winners and losers, but the adaptation to them in competitive markets reallocates resources to maximize the value of production. Efficient adaptation results in situations where the winners from a change can compensate the losers and still be winners; that is, be better off. ${ }^{15}$

NEB practice and controversy over the role of economic efficiency in one of its recent tolling decisions makes clear the need for legislative reform that equates economic efficiency and the public interest in the NEB Act. Such an amendment would preclude the NEB from following its practice of defining the public interest as (NEB 2016e, 1):

The public interest is inclusive of all Canadians and refers to a balance of economic, environmental, and social interests that changes as society's values and preferences evolve over time.

This approach allows the NEB the flexibility to trade off various considerations as it deems appropriate. This includes the flexibility to ignore economic efficiency. In a recent decision on tolling methodology the NEB held that it is not required to consider economic efficiency in assessing whether tolls are in the public interest under the NEB Act (NEB 2017c, 9-10). Moreover one of the factors it must consider, whether tolls are just and reasonable, is a matter of its "informed judgment and opinion" (NEB 2017c, 4) and not their effect on economic efficiency. The argument in this Commentary is that the NEB's definition of the public interest and the provisions of the NEB Act that purport to provide direction with respect to the public interest are not in the public interest.

Adopting the goal of economic efficiency for public utility regulation involves identifying the most efficient outcome; that for which value is maximized. There are two common objections to this approach. The first is that many important regulatory concerns, in particular environmental and safety concerns, would be excluded from regulatory consideration. The second is that it ignores the distributional consequences of regulatory policy.

For example, the NEB is concerned with the exercise of monopoly power by pipelines, but its regulatory scope also extends to safety and environmental concerns associated with pipelines. These issues, and not whether tolls are too high, are more likely the concern of landowners and communities near proposed facilities regulated by the NEB. However, such a safety or environmental objection fundamentally misunderstands the nature of efficiency analysis. Efficiency analysis addresses differences in values over resource use by translating differences in preferences and intensity of preferences into dollars. Determining whether a pipeline should be permitted to cross a river or the appropriate thickness of a pipeline's walls should not be viewed as a "clash of values" requiring mediation by regulators or politicians. Instead, these

14 An efficient state is socially desirable because it is not possible to make one person better off without making someone else worse off. An efficient state is Pareto Optimal.

15 If the winners from such a change can compensate those harmed by the change and still be better off, then the change is a Potential Pareto Improvement. A change where one person is made better off and no one is made worse off is a Pareto Improvement. If no Pareto Improvements are possible, then the allocation is Pareto Optimal.

16 An activity might be "priced" by governments to reflect any negative external effects on others. In this case, the externality would be incorporated explicitly in private decisions, and the regulator would not require extra accounting for those external effects. 
issues should be viewed as questions regarding resource allocation and resolved by the regulator determining efficient use.

Concerns over environmental impact often arises because of the imposition of costs on others through the use of resources that are not priced. But there is no reason why, in principle, these "external costs" cannot be incorporated into a regulator's efficiency analysis. ${ }^{16}$ If, for example, the presence of high-voltage transmission lines reduces property values, then an efficiency mandate requires the regulator to take that loss into account in determining the social costs of those lines. And when it does so, it may be in a position to determine the compensation to those whose resources would be used, or whose value would be reduced, and require that compensation be paid, leaving both the proponents of the project and those harmed by its environmental consequences better off.

The analysis of safety considerations should also be based on economic efficiency. The extra costs of enhanced safety should be compared to the expected benefits. For example, in the case of oil spills from a pipeline rupture, efficiency requires that the marginal cost of enhanced safety equal its expected marginal benefit. If the marginal cost exceeds the benefit, then society is better off if the resources allocated to extra safety are used instead in their next-best alternative use. In many cases, the risk of an oil spill will be reflected in nearby property values, and the value of enhanced safety expenditures will be reflected in reduced impacts on property values of a pipeline. ${ }^{17}$ The effect on property values of pipelines or changes in pipeline safety regulations can be used to determine external costs and to assess compensation to those harmed.
A second objection to adopting the policy goal of efficiency is the potential for the distributional consequences of the efficient outcome to be undesirable: a focus on efficiency requires that those that benefit could compensate those made worse off, not that they must. Indeed, to the extent safety and environmental concerns are not about appropriately internalizing negative effects on others, but instead over whether efficient development of natural resources should proceed, the concern is not about the efficient allocation of resources. Instead, it is about income distribution and that is better left to governments. While income distribution is important, its consideration should not be part of the regulatory process. As noted below, there are better mechanisms to address income distribution.

\section{Rationales for Regulation}

There are two distinct rationales for intervening in the market provision of services by a public utility. The first is to enhance economic efficiency. In general, markets allocate resources to maximize value and are efficient. But sometimes they are not, in which case regulation can be a response to this market failure and is justified because it improves economic efficiency. Well-designed and implemented regulation may be able to increase the value of resources in situations where markets do not result in maximization of the value of the output of resources.

Consider natural gas distribution. Natural gas distribution is a natural monopoly: cost minimization requires a single provider to avoid wasteful duplication of large sunk investments in a network of pipelines. Regulation achieves cost minimization by restricting production to a single

17 To see the logic of efficiency, suppose that existing regulatory measures impose a $\$ 1$ million cost on a pipeline, but the reduction in the expected cost of a rupture is only $\$ 250,000$. The pipeline and the landowners would be better off if the regulator relaxed safety measures and instead required the pipeline to pay the landowners $\$ 500,000$. Both the pipeline and the landowners would be better off, and the cost to society of the expected oil spill in terms of resource use is minimized. 
provider. Price regulation is required to control the resulting monopoly power and promote allocative efficiency. In such circumstances, regulation can result in the efficient level of output produced at minimum cost.

Alternatively, in the absence of regulation, a pipeline may well underinvest in safety, thereby imposing external costs on others. Regulatory intervention can improve the efficiency of resource allocation by forcing the pipeline to take into account not only its private costs, but also the external costs it imposes on others, leading to the requirement that a pipeline's social benefits exceed its social cost.

The second rationale for intervention is to redistribute the gains from economic activity. In this way, regulation is justified as a policy mechanism to transfer effective resource control to favoured groups, while regulatory decisions use the state's coercive power to reallocate the benefits of economic activity to those groups.

Political inefficiency arises when governments destroy wealth by misallocating resources in exchange for the inputs that contribute to acquiring and maintaining political power. For instance, when telephony was subject to price regulation, it was common practice to build cross subsidies into the regulated service rates. Regulators mandated high prices for long-distance telephone calls and business services and then used the profits to subsidize rates for local residential service. In the US, the loss in value from the inefficient pricing of telecommunications services by regulators was estimated to be $\$ 8$ billion per year (Crandall and Waverman 1995). A second example of how a government destroys wealth is a decision to prohibit construction of a pipeline, even if landowners have reached an agreement to provide access and the construction is economically efficient. In this case, the resource, land, is restricted by regulation to a lower value use.

\section{Politicians versus Regulators: the Delegation of Authority}

Public Choice analysis makes clear the danger, even if policymakers implement regulation with the best of intentions, to correct market failure and enhance economic efficiency. Inevitably, politicians and special interest groups will try to subvert the process. The accumulated wisdom of how governments actually make choices indicates the importance of limiting potential political inefficiency when designing non-market regulatory institutions, as well as the allocation of authority and the design of regulatory institutions. Minimizing political interference and its resulting inefficiency is an important basis for leaving decisions to independent regulatory agencies when the rationale for regulation is economic efficiency; i.e., wealth creation.

A key reason for delegating responsibility for decisions that have significant implications for the efficient allocation of resources is to insulate these decisions from the political process. It is much more difficult for governments to intervene or change regulatory decisions if those decisions are based on economic efficiency. The reason is that the pressure for intervention or disagreement will not be based on economic efficiency, but on the decision's distribution implications; i.e., who is more deserving. This means that governments will likely be much more cautious about intervening on distributional grounds because it is much harder to argue that their intervention is in the public interest. Moreover, even if the redistribution is warranted, there are much less costly ways to redistribute income than through regulatory decisions.

\section{Implications for Regulatory Practice}

Clearly, the design of regulatory agencies should reflect the advantages of insulating their independent decisions from the political process. One characteristic of an effective regulatory process 
- one that is relatively more immune from political considerations - is that its enabling legislation has a clear emphasis on efficient resource allocation. The public interest that regulation is intended to serve should be clearly articulated as the promotion of economic efficiency. Regulators should not be concerned with the distributional implications of their decisions. A legislative requirement that regulators and the regulatory process should be concerned only with determining the effect of decisions on resource allocation would have a number of important beneficial implications.

The first positive from such a focus is that it defines, and constrains, the relevant evidence. The focus of relevant evidence would be on the effect of alternatives on the efficient allocation of resources. This makes the only relevant evidence the aggregate benefits and costs of different alternatives. An immediate implication is that regulatory processes which were never intended to be a substitute political process to express preferences over the appropriate use of resources will cease to be so. Instead, the preferences of society are represented, from the perspective of the regulator, by aggregate costs and benefits. Regulators would then have no need to consider evidence that does not inform the costs and benefits of alternatives. The regulatory process would no longer be concerned with the fairness of the outcome or with providing everyone with an equal opportunity to participate. The result would be less expensive and more timely decisionmaking, with a lower probability of an error.

The second benefit of a focus on economic efficiency is that it implies regulators would need to have the relevant expertise and background, precluding most patronage appointments (Martin 2015).

Third, a focus on economic efficiency and competent regulators would minimize the temptation for the government to intervene and constrain a regulatory board's powers by writing detailed rules into the legislation or accompanying regulations. Indeed, regulation by government legislation is usually inefficient in a world of change and uncertainty. Detailed legislation that specifies how regulators are to exercise their authority limits the flexibility of the regulator to adapt as (i) circumstances change, (ii) the legislature's assessment of what is important turns out to be wrong, or (iii) there are unforeseen developments. Changing legislation is likely to be either difficult or reactionary, resulting in a regulatory policy that is out of date and out of touch.

A fourth and final benefit of an economicefficiency focus is that it avoids the temptation to change regulatory institutions based on a perception that they are costly and/or ineffective. The perception can be true, but the source is not the regulatory institutions, but their use. Regulatory institutions and processes have not been designed, and likely cannot be designed, to arbitrate competing preferences. Elections for public office are how competing preferences should be reconciled, subject of course to constitutional protection of rights.

\section{Preserving Incentives for Investment}

The importance of a regulatory process that is stable, predictable and informed by principles of wealth creation is highlighted by the regulatory risk that can arise when investment is large and sunk. In these circumstances, firms will be reluctant to invest unless they have confidence that regulators will respect their property rights. If the regulatory process is subject to distributional concerns, there is always a temptation that the regulator will be seduced by pressure from consumers, or others, to essentially expropriate a firm's sunk capital investment.

Regulatory holdup occurs when the regulator takes measures after investments have been made that make those investments unprofitable. This can be done by reducing prices after the investment 
in sunk capital to reflect only variable costs and not total costs. The latter includes return on, and of, capital, but the former does not if capital investment is sunk. It can also occur if the regulator liberalizes entry conditions, and competitive entry results in lower prices and stranded investment, or if the regulator imposes new obligations that raise service costs.

An example of regulatory holdup is the evolution of the CRTC's policy with respect to competitors' access to the incumbent telephone companies' investment in high-speed Internet access facilities, in particular, fibre optic broadband to the home.

The CRTC mandated access to competitors at regulated rates after investment in these facilities had commenced (CRTC 2015, 136 and 144). This was a flip flop. In 2008, the CRTC found that fibre access facilities were non-essential and mandated access was to be phased out (CRTC 2008, 119). The CRTC had also confirmed in its matching speed decision that fibre to the home was not included in the set of facilities for which mandated access was required (CRTC 2010, 121).

Another regulatory holdup example is the CRTC's decision to prohibit simultaneous substitution of Canadian commercials for US ones on the American network Super Bowl broadcast, starting in 2017. The CRTC ruled that this ongoing "simsub" is "not in the public interest" and rejecting it was necessary to fulfill "the policy objectives of the [Broadcasting] Act" (CRTC 2016, 40 and 24) based on its determination that the US ads are "integral to the event itself" (CRTC 2016, 5 and 26). In issuing its order prohibiting the usual practice by Canadian networks, the CRTC acknowledged that Bell Media had entered into a multiyear contract with the National Football League for the Canadian broadcast rights for the Super Bowl based on the expectation of simultaneous substitution. However, the CRTC rejected Bell Media's claim that its resulting lost advertising revenue and the existence of a contractual right should impact its decision (CRTC 2016, 56). Bell Media estimated it would lose $\$ 80$ million in unrealized advertising revenue over the length of the contract (CARTT 2016).

The NEB's approval of the Canada-US Alliance pipeline is a third example (Daljevic 2016). The effect of this approval resulted in the transfer of large volumes of natural gas from TransCanada's mainline to the Alliance pipeline and the creation of substantial excess pipeline capacity. The result was an extended regulatory battle between the NEB and TransCanada over tolling changes to the mainline that would reduce the non-recovery of investments in the mainline.

Finally, regulatory holdup occurs when the regulator strands investment by non-regulated firms whose sales depend on timely development of supporting infrastructure. This occurs when non-regulated firms invest in sunk capacity with the expectation that sufficient infrastructure will be available on a timely basis, but the regulator delays or effectively prohibits the expected investment in regulated assets. The constraints in Canada on pipeline export capacity for oil sands production is an important, and topical, example.

The advantage to society of an economicefficiency mandate for regulators is that it enhances the likelihood that the regulator will not hold up regulated companies who invest in sunk capital. That is, the regulator can more readily resist demands that, in the short run, have immediate benefits for some, but in the long run destroy the incentive for investment and wealth creation (Spiller and Tommasi 2005). Moreover, its efficiency-enhancing decisions are less likely to be appealed, or overturned, by the courts. A reputation for not succumbing to short-run interests is easier for a regulatory institution to develop and maintain than a government. Furthermore, it is important to have credible regulatory institutions looking at the 
longer run, especially in systems where parliament is paramount and policy can be reversed with a change of government or even by a single vote. ${ }^{18}$

\section{DISTRIBUTIONAL CONCERNS}

Income distribution is clearly an important concern, so legislators should not allocate its responsibility to regulators. Instead, there should be an institutional division of labour with the legislative branch responsible for income distribution. ${ }^{19}$ The value judgment appropriate for an autonomous unelected body is economic efficiency and wealth creation, not the determination of the appropriate distribution of the gains from economic activity. ${ }^{20}$

A consistent focus on economic efficiency as the objective of regulation will, on average, make everyone better off in the long run. If some people are consistently disadvantaged and left behind, then distributive bodies responsible to elected representatives can transfer income to them. Moreover, those harmed by one decision might well benefit from others. Piecemeal responses within the regulatory system to address those disadvantaged are costly and may be either ineffective or redundant. Finally, if regulation is seen simply as another means to engage in rent seeking and redistribution, then it will lose legitimacy, even if it was justified on the basis of economic efficiency.

\section{A HOPEFUl SIGN FOR ECONOMIC EFFICIENCY}

Last year, the Senate's Standing Committee on Transportation and Communications released a report on pipeline regulation, highlighting the inefficiency - the lost value to the Canadian economy - arising from a reluctance to build new pipelines to export crude oil. In its view the benefits outweigh the costs (Senate 2016, 8) and it urged regulatory reform to develop a consensus that additional pipeline capacity is in the public interest (Senate 2016, 6).

The committee advocated four important reforms to institute an apolitical, fact-based, inclusive process for pipeline approvals (Senate 2016, 1). They are:

- Remove the requirement that pipelines are subject to federal government approval. Instead, allow for NEB decisions to be subject to cabinet appeal (Senate 2016, 2).

18 Ironically, this is illustrated by the Super Bowl broadcast debacle. In the absence of a narrowly defined efficiency mandate, the CRTC determined that the policy objective of "allowing subscribers to view complete (i.e., unaltered) programming" overcomes the negative effect on advertising revenues for Canadian broadcasters (CRTC 2016, 39) and the cost of increased regulatory risk. In response to lobbying by the National Football League, the Prime Minister's Office responded that the CRTC was an independent agency, its regulatory decision was not reviewable by the government and its policy decisions under the Broadcasting Act could not be reversed (Jackson 2017). This nicely illustrates the point that allocating responsibility to independent decision-makers provides a shield to governments, which could, if they wanted, amend the offending legislation.

19 There is a long tradition in the economics literature supporting the desirability of such division of labour (see Wicksell 1896, Musgrave 1959, and Buchanan and Tullock 1962; for a summary of the discussion, see Mueller 2003, Chapter 29).

20 For a discussion of how the Canadian Competition Tribunal has incorporated distributional considerations without making its own assessment on the appropriate distribution of income, see Ross and Winter (2005). The Federal Court of Appeal required the Competition Tribunal to adopt considerations other than economic efficiency despite its legislative mandate, though not a sole mandate, to consider economic efficiency in its decision-making. In its Superior Propane redetermination, the Tribunal incorporated distributional considerations, using evidence about redistribution from Canada's taxation and public expenditure regimes. The Tribunal adopted an efficiency standard except that they counted as a cost transfers (lost surplus from higher propane prices) from consumers in the bottom quintile of the income distribution. 
- Allow for more participation by Canadians in NEB hearings by expanding participation beyond those either directly affected by the pipeline or with specific information or expertise (Senate 2016, 14-15).

- Increase the scope of NEB reviews to encompass all environmental costs specific to a pipeline (Senate 2016, 14-15).

- Align and integrate consultations between Indigenous peoples and the federal government with the NEB regulatory review (Senate 2016, 14-15).

The committee's recognition that the benefits of pipeline expansion exceed the cost is a welcome acknowledgement. This economic efficiency focus and the finding that the public interest can be assessed by comparing costs and benefits should be enshrined in the NEB Act. The suggestion to include broader environmental concerns is also consistent with the recommendations in this

\section{Commentary.}

While the committee's desire for expert consideration and an apolitical process is also reflected here, these goals are more likely to be achieved by adopting an efficiency objective. It is unlikely that substituting appeals to cabinet for the current required government approval will be effective in eliminating lobbying, rent seeking and political inefficiency. Similarly, broadening the scope for participation is likely to be counterproductive, more likely to give rise to frustration and hostility by those who are given a voice but whose preferences are ignored, and it is at odds with the desired efficiency focus. ${ }^{21}$

Finally, and perhaps most importantly, the issues related to Indigenous peoples is a dispute about control of resources, which is properly characterized as a dispute about income distribution. This is not, and should not, be addressed by the NEB. Instead, it will eventually have to be addressed by the federal government and will likely not be resolved until the property rights of Indigenous peoples are settled.

\section{CONCLUSION}

The implication of this analysis is that the controversy over pipelines and other regulated industries will not be reduced, let alone eliminated, by expanding the scope of consultations and widening public participation. ${ }^{22}$ Regulatory processes are not substitutes for the political process. Instead, regulators should be concerned with economic efficiency: maximizing the value of the goods and services produced by the Canadian economy. The distribution of those goods and services should not be a consideration in regulatory decision-making. Instead, concerns over distribution should be addressed by legislatures. Limiting the public-interest mandate of an independent regulator to questions of economic efficiency is more likely to result in regulation that contributes to increased productivity, enhanced real incomes and a higher standard of living.

21 See Cattaneo (2017) for a discussion of environmental groups' response to Ottawa's approval of the Trans Mountain Expansion and the Enbridge Line 3 Replacement Project, including arranging a visit to the oil sands by Jane Fonda.

22 The debacle of the Energy East proceedings before the NEB is seen as evidence by some that the problem is not that the process was not "fair and robust" or provided limited opportunity for participation, but the exact opposite (Hislop 2016; Cattaneo 2016c; O’Neil 2016). Indeed, at least one Senator has observed that the NEB is not the appropriate venue to address issues that are more appropriate for the federal government to resolve and that its mandate should be narrowed (Yedlin 2016). 


\section{REFERENCES}

Acemoglu, D., and J. Robinson. 2012. Why Nations Fail: The Origins of Power, Prosperity, and Poverty. Crown Business: New York.

Bailey, I. 2017. "Donations taint B.C.'s approval of Trans Mountain pipeline expansion: advocacy groups." Globe and Mail, 31 January. Available online at http://www.theglobeandmail.com/news/ british-columbia/clark-in-conflict-of-interestover-trans-mountain-pipeline-approval-groups/ article33852858/.

Government of British Columbia. 2012. British Columbia outlines requirements for heavy oil pipeline consideration. News Release. 23 July. Available online at https://news.gov.bc.ca/stories/british-columbiaoutlines-requirements-for-heavy-oil-pipelineconsideration.

2017. Five conditions secure coastal protection and economic benefits for all British Columbians. News Release, 11 January. Available online at https://archive. news.gov.bc.ca/releases/news_releases_20132017/2017PREM0002-000050.htm.

Buchanan, J., and G. Tullock. 1962. The Calculus of Consent. University of Michigan Press: Ann Arbour.

Government of Canada. 2012. Budget 2012 - Jobs, Growth, and Long-Term Prosperity: Economic Action Plan 2012. Available online at http://www.budget. gc.ca/2012/plan/pdf/Plan2012-eng.pdf.

. 2014. Budget 2014 - The Road to Balance: Creating Jobs and Opportunity. Available online at http://www.budget.gc.ca/2014/docs/plan/ pdf/budget2014-eng.pdf.

2016a. Backgrounder - Interim Measures for Pipeline Reviews. 27 January. Available online at http://news.gc.ca/web/article-en.do?nid=1029989.

. 2016b. Government of Canada announces pipeline plan that will protect the environment and grow the economy. 29 November. Available online at http://news.gc.ca/web/article-en. do? $m$ thd $=$ advSrch\&crtr.page=1\&nid=1162449.
Government of Canada. 2016c. Backgrounder: Trans Mountain Expansion Project. 29 November. Available online at https://www.nrcan.gc.ca/energy/ resources/19142.

CARTT. 2016. "Super Bowl Simsub Battle: Less than six weeks before kick off, Bell, NFL re-file appeals." 28 December. Available online (with subscription) at https://cartt.ca/article/super-bowl-simsub-battleless-six-weeks-kick-bell-nfl-re-file-appeals.

Cattaneo, C. 2016a. "Ottawa's game plan on climate change in shambles as Energy East hearings spiral into soap opera." National Post. 30 August. Available online at http://business.financialpost.com/news/ energy/ottawas-gameplan-on-climate-change-inshambles-as-energy-east-hearings-spiral-into-soapopera.

_. 2016b. "How National Energy Board efforts to engage with Quebec backfired with claims of improper behaviour." National Post. 2 September. Available online at http://business.financialpost. com/news/energy/how-national-energy-boardefforts-to-engage-with-quebec-backfired-withclaims-of-improper-behaviour.

. 2016c. “Ottawa's game plan on climate change in shambles as Energy East hearings spiral into soap opera." National Post. 30 August. Available online at http://business.financialpost.com/news/ energy/ottawas-gameplan-on-climate-change-inshambles-as-energy-east-hearings-spiral-into-soapopera.

2017. "Honeymoon is Over Between Trudeau and Anti-Oil Activists." Calgary Herald, 11 January, B1.

CBC News. 2007. “Top EUB officials retire in wake of spying controversy Total of 6 people have left agency in last 3 months." CBC News. 21 November. Available online at http://www.cbc.ca/news/canada/ edmonton/top-eub-officials-retire-in-wake-ofspying-controversy-1.645514. 
Church, J., et al. 2009. Transmission Policy in Alberta and Bill 50. School of Public Policy, University of Calgary.

Church, J., and R. Ware. 2000. Industrial Organization: A Strategic Approach. Irwin McGraw-Hill: San Francisco.

Colton, J., et al. 2016. Energy Projects, Social License, Public Acceptance and Regulatory Systems in Canada: A White Paper. School of Public Policy, University of Calgary.

Coyne, A. 2016. "Wynne shamed into campaign financing changes while Clark just shrugs." National Post. 6 May. Available online at http://news. nationalpost.com/full-comment/andrew-coynewynne-shamed-over-shady-campaign-financingwhile-clark-just-shrugs.

Cheadle, B. 2016. "'Modest' delays possible in Energy East review." Calgary Herald. 14 September. B1.

Cheadle, B. 2017. "Pipeline battle ramps up with Trans Mountain challenge." National Post, 21 December, FP1 and FP6.

Crandall, R., and L. Waverman. 1995. Talk is Cheap. The Brookings Institution: Washington, D.C.

CRTC. 2008. Revised regulatory framework for wholesale services and definition of essential service. Telecom Decision CRTC 2008-17. 3 March.

. 2010. Wholesale high-speed access services proceeding. Telecom Regulatory Policy CRTC 2010632. 30 August.

2015. Review of wholesale wireline services and associated policies. Telecom Decision CRTC 2015326. 22 July.

. 2016. Simultaneous substitution for the Super Bowl. Broadcast Regulatory Policy CRTC 2016334 and Broadcasting Order CRTC 2016-335. 19 August.

Daljevic, M. 2016. The Regulatory Compact and the Treatment of Stranded Assets. MPP Capstone Project, School of Public Policy, University of Calgary.

Dachis, B. 2015. Railroad Blues: How to Get Canada's Rail Policy Back on Track. C.D. Howe Institute.
Dachis, B,. and D. Schwanen. 2016. Changing the Channel on Canadian Communications Regulation. C.D. Howe Institute.

Doucet, J. 2012. Unclogging the Pipes: Pipeline Reviews and Energy Policy. C.D. Howe Institute.

Ferguson, N. 2011. Civilization: The West and the Rest. Penguin Press: New York.

Globe and Mail. 2016. "Ontario's new electricity policy: History repeats as farce." Globe and Mail. 13 September. Available online at http://www. theglobeandmail.com/opinion/editorials/ontariosnew-electricity-policy-history-repeats-as-farce/ article31862790/.

Hislop, M. 2016. “Keystoning' Energy East.” National Post. 13 September. FP 7.

Hunter, J., and W. Stueck, "B.C. government to Northern Gateway pipeline proposal: 'No'." Globe and Mail. 17 July. Available online at http://www. theglobeandmail.com/news/british-columbia/bc-tonorthern-gateway-no/article19213866/.

Jackson, E. 2017. "NFL lobbied prime minister's office, MPs to overturn CRTC Super Bowl Ad decision." National Post. 4 January. Available online at http:// business.financialpost.com/fp-tech-desk/nfllobbied-prime-ministers-office-mps-to-overturncrtc-super-bowl-ad-decision?_lsa=073a-374f.

Martin, L. 2015. "It's time to take down the spoils system." Globe and Mail. 9 June. Available online at http://www.theglobeandmail.com/opinion/its-timeto-take-down-the-spoils-system/article24863562/.

McCarthy, S., and J. Lewis. 2016. "Court overturns Ottawa's approval of Northern Gateway pipeline." Globe and Mail. 30 June. Available online at http:// www.theglobeandmail.com/report-on-business/ industry-news/energy-and-resources/federal-courtoverturns-ottawas-approval-of-northern-gatewaypipeline/article30703563/. 
McSheffrey, E., and J. Uechi. 2016. "NEB sides with Texas-based pipeline company against B.C. citizens, First Nations." National Observer. 19 May. Available online at http://www.nationalobserver. com/2016/05/19/news/neb-expected-approvekinder-morgan-trans-mountain-expansion-today.

Morrow, A. 2016. "Ontario Liberals held more than 90 cash-for-access fundraisers in two-year span." Globe and Mail. 9 May. Available online at http://www.theglobeandmail.com/news/ national/ontario-liberals-held-more-than-90cash-for-access-fundraisers-in-two-year-span/ article29948904/?1467478898501.

Mueller, D. 2003. Public Choice III. Cambridge University Press: New York.

Musgrave, R. 1959. The Theory of Public Finance. McGraw- Hill: New York.

National Energy Board. 2015. Hearing Order OH001-2014 Trans Mountain Pipeline ULC (Trans Mountain) Application for the Trans Mountain Expansion Project (Project) Procedural Direction No. 15 - Oral summary argument: schedule and further logistical details. 28 July. Available online at https://docs.neb-one.gc.ca/1l-eng/ llisapi.dll/fetch/2000/90464/90552/548311 /956726/2392873/2449981/2810001/ A194\%2D1_\%2D_Procedural_Direction_ No._15_\%28French_included\%29_\%2D_A4R7W4. pdf ? nodeid=2809627\&vernum $=-2$.

\section{6a. Suspension of Energy}

East Panel Sessions. Nerws Release. 30 August.

Available online at http://news.gc.ca/web/article-en. do?mthd=tp\&crtr.page $=1 \&$ nid $=1118559$.

\section{6b. Energy East Hearing}

Panel Steps Down. News Release. 9 September. Available online at http://news.gc.ca/web/article-en. do? $m$ thd=tp\&crtr.page=1\&nid=1122609.

\section{6c. Decision Statement of the} NEB Chair and Vice-Chair. 9 September. Available online at https://docs.neb-one.gc.ca/11-eng/llisapi. dll?func=11\&objId=3052509.
. 2016d. NEB Welcomes New

Temporary Board Members. News Release. 12

December. Available online at https://www.neb-one. gc.ca/bts/nws/whtnw/2016/2016-12-12-eng.html. 2016e. NOVA Gas Transmission Ltd. Facilities, Tolling Methodology. Decision GH003-2015, October. (Towerbirch Report). 2017a. NEB names new Energy

East Hearing Panel. News Release. 9 January. Available online at http://news.gc.ca/web/article-en. do?nid=1177199.

East Pipeline Ltd. and TransCanada Pipelines

Limited Hearing for the Energy East Project and Asset Transfer and Eastern Mainline Project Ruling No. 1 Consequences of the Energy East Hearing panel's recusal and how to recommence the Energy East Hearing. 27 January. 2017c. Application for Review of the Decision of Members Ballem and Lytle, in Report GH-003-2015 (Towerbirch Report), Respecting the Toll Treatment of the Tower Lake Section (TLS) Letter Decision, N081-2015-16-03, March.

National Post. 2016. "The ugliness of Liberal actions." National Post. 17 December. Available online at https://www.pressreader.com/canada/national-postnational-edition/20161217/281689729456914.

Noll, R. 1989. “Economic Perspectives on the Politics of Regulation." in R. Schmalensee and R. Willig, Handbook of Industrial Organization. North-Holland: Amsterdam, pp. 1253-1288.

O’Neil, P. 2016. “Ottawa's 'social licence' denies local voice on energy megaprojects.” Calgary Herald. 21 September. B3.

Peltzman, S. 1976. "Toward a More General Theory of Regulation." Journal of Law and Economics 19: 211240.

Posner, R. 1974. "Theories of Economic Regulation.” Bell Journal of Economics 5: 335-358. 
Rising Tide Toronto. 2014. In Response to NEB decision, Rising Tide Toronto launches "Line 9 Pledge of Resistance". 6 March. Available online at http:// toronto.mediacoop.ca/fr/story/response-nebdecision-rising-tide-toronto-launches/22085.

Ross, T., and R. Winter. 2005. “The Efficiency Defense in Merger Law: Economic Foundations and Recent Canadian Developments." Antitrust Law Journal 72: 471-503.

Senate Standing Committee on Transport and Communications. 2016. Pipelines for Oil: Protecting Our Economy, Respecting Our Environment. December.

Spiller, P., and M. Tommasi. 2005. "The Institutions of Regulation: An Application to Public Utilities.” in C. Menard and M. Shirley, Handbook of New Institutional Economics. Springer: New York, pp. 515544.

Stigler, G. 1971. "The Theory of Economic Regulation.” Bell Journal of Economics 2: 3-21.
Watson, W. 2016. The Inequality Trap: Fighting Capitalism Instead of Poverty. University of Toronto Press: Toronto.

Wente, M. 2016. "Wynne's way: Rob the poor, help the rich." Globe and Mail. 12 September. Available online at http://www.theglobeandmail.com/ opinion/wynnes-way-rob-the-poor-help-the-rich/ article31835620/.

Wicksell, K. 1896 (1967). "A New Principal of Just Taxation." in R. Musgrave and A. Peacock, Classics in the Theory of Public Finance. St. Martin's Press: New York, pp. 72-118.

Woolley, A. 2008. "Enemies of the State? The Alberta Energy and Utilities Board, Landowners, Spies, a $500 \mathrm{kv}$ Transmission Line and Why Procedure Matters." Journal of Energy \& Natural Resource Law 26: 234-266.

Yedlin, D. 2016. "Senate committee another voice for urgency of pipelines." Calgary Herald. 23 September. B1-B2. 
NOTES: 
NOTES: 
NOTES: 


\section{ReCent C.D. Howe institute Publications}

avril 2017

April 2017

April 2017

April 2017

April 2017

March 2017

March 2017

March 2017

mars 2017

March 2017

March 2017

February 2017

Busby, Colin, Aaron Jacobs, et Ramya Muthukumaran. Besoin d'un rappel? Comment améliorer la couverture vaccinale des enfants au Canada. Institut C.D. Howe commentaire 477.

Busby, Colin, Aaron Jacobs, and Ramya Muthukumaran. In Need of a Booster: How to Improve Childhood Vaccination Coverage in Canada. C.D. Howe Institute Commentary 477.

Robson, William B.P., and Colin Busby. Numbers You can Trust? The Fiscal Accountability of Canada's Senior Governments, 2017. C.D. Howe Institute Commentary 476.

Robins, Steven. "Surge Capacity: Selling City-owned Electricity Distributors to Meet Broader Municipal Infrastructure Needs." C.D. Howe Institute E-Brief.

Brown, Robert L., and Shantel Aris. Greener Pastures: Resetting the Age of Eligibility for Social Security Based on Actuarial Science. C.D. Howe Institute Commentary 475.

Schwanen, Daniel, and Aaron Jacobs. Patents, Copyright and Competition: Assessing the Impact of Trade Deals on Canada. C.D. Howe Institute Commentary 474.

Dachis, Benjamin. New and Improved: How Institutional Investment in Public Infrastructure can Benefit Taxpayers and Consumers. C.D. Howe Institute Commentary 473.

Robson, William B.P., Aaron Jacobs, and Benjamin Dachis. "Equipment Failure: Feeble Business Investment Costs Canadians their Competitive Edge.” C.D. Howe Institute E-Brief.

Oschinski, Matthias et Rosalie Wyonch. Le choc du futur? Les répercussions de l'automatisation sur le marché du travail au Canada. Institut C.D. Howe commentaire 472.

Oschinski, Matthias, and Rosalie Wyonch. Future Shock? The Impact of Automation on Canada's Labour Market. C.D. Howe Institute Commentary 472.

Krane, Joshua, and Brian Facey. "Promoting Innovation and Efficiency by Streamlining Competition Reviews.” C.D. Howe Institute E-Brief.

Sen, Anindya. Smokes, Smugglers and Lost Tax Revenues: How Governments Should Respond. C.D. Howe Institute Commentary 471.

\section{SUPPORT THE INSTITUTE}

For more information on supporting the C.D. Howe Institute's vital policy work, through charitable giving or membership, please go to www.cdhowe.org or call 416-865-1904. Learn more about the Institute's activities and how to make a donation at the same time. You will receive a tax receipt for your gift.

\section{A REPUTATION FOR INDEPENDENT, NONPARTISAN RESEARCH}

The C.D. Howe Institute's reputation for independent, reasoned and relevant public policy research of the highest quality is its chief asset, and underpins the credibility and effectiveness of its work. Independence and nonpartisanship are core Institute values that inform its approach to research, guide the actions of its professional staff and limit the types of financial contributions that the Institute will accept.

For our full Independence and Nonpartisanship Policy go to www.cdhowe.org. 

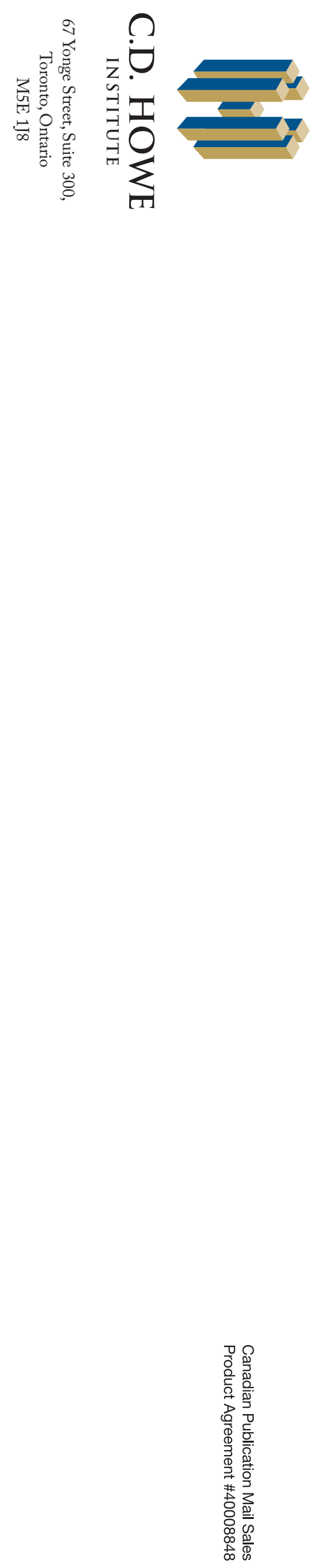